\title{
実用的制限条件を考慮した変断面ばりの塑性設計に関する一考察

\author{
PLASTIC DESIGN OF BEAMS WITH VARIABLE CROSS SECTIONS \\ CONSIDERED THE PRACTICAL CONSTRAINTS
}

\author{
伊藤 満* ・福本唀士** \\ By Mitsuru ITO and Yuhshi FUKUMOTO
}

\begin{abstract}
The purpose of this paper is to present a plastic design method of two-span continuous beams with variable cross section which is satisfied the requirements of deflection and stress constraints at service loads. This design is also intended to minimize the structural weight of the beams, and is shown a procedure to determine the modified stepped moment distributions correspond to the required plastic moment distributions in order to perform the practical design. Design loads are of any combinations of moving single and distributed live loads and dead load which are usually considered as bridge loadings.
\end{abstract}

\section{1. 緒言}

鋼構造物の塑性設計は, 構造部材の単位重量と塑性 モーメントの間の相関性を利用して, 構造重量の最小化 を図ることが比較的容易にできる，塑性設計にこうした 簡便さのある反面, 最小重量設計された構造物は, 構造 物の崩壊強度が明確であることと, 最小重量であること 以外, 他の㑉性, 応力などの制限条件についてはなんら 保証されていない.

塑性設計を実際の橋梁構造物に適用していくために は,たわみ, 応力などの制限条件をも考慮する必要があ り, 得られた設計は同時に, 経済設計のために変断面と し，最小重量設計であることが望まれる11.

塑性設計の分野において , 塑性強度とともに, たわみ, 応力などの制限条件を同時に満たす塑性設計法の研究 は，たとえば，文献 2)，3）に紹介されている. 文献 2)， 3) の中の研究は, 建築構造物, 主として, ラーメン構 造物を対象としたものである.

Melchers ${ }^{4}$ は, 最近, 塑性設計から得られた情報を用

* 正会員 工博 立命館大学教授 理工学部土木工学科 ( ₹ 603 北区等持院北町 56-1)

** 正会員 Ph.D. 工博 名古屋大学教授 工学部土木工学 科 ( 464 名古屋市千種区不老町)
いて, 弾性たわみを評価する方法についての提案を行っ ている. 彼の方法は，塑性設計断面を補強することによ って, たわみを許容值内に収めようとするものである. また, 構造重量の経済性についてはふれていない.

$\mathrm{Azad}^{5)}$ は, 等分布荷重を受ける 3 径間連続ばりの最小 重量塑性設計を行い, 経済的スパン割りと, 腹板高一定 とした場合の経済的桁高さを求めている. 彼の最小重量 塑性設計は, 構成断面の寸法值を用いて析重量を求める もので, 実際の設計により近いものとなっているが，た わみ, 応力などの制限条件についてはふれていない.

石川ら ${ }^{6) .71}$ は, 弾性時におけるたわみ, 応力の制限条 件と同時に, 終局時における塑性崩壊の条件を考虑した 最小重量設計の問題を数理計画法の問題に置き換えて解 いている. 例として, 簡単な不静定トラス, および, 2 層 4 スパンラーメンを扱っている.

本研究は, 比較的簡単な方法で最小重量塑性設計され たはりが, 作用荷重を受けたときのたわみ制限, 応力制 限をも同時に満足するという，いわゆる，実用的制限条 件を考慮した変断面ばりの最小重量塑性設計法について の 1 つの提案 ${ }^{8)}$ を行うものである. 対象としたはりは等 スパン 2 径間連続ばりである. また, 先に著者らが行っ た重量最小化のみを目的とした塑性設計 ${ }^{91.10)}$ との比較検 討を行うものである. 


\section{2. 変断面設計}

\section{（1）用いた仮定と条件}

1）使用鋼材は理想弾塑性体とする.

2）たわみおよび全塑性モーメントに及ぼすせん断力 の影響は無視する.

3）はりは塑性ヒンジを形成することのできる断面構 成とする。

4）変断面等スパン 2 径間連続ばりを解析の対象とす る.

5）線荷重として単位幅員当たり $P$ の荷重がはり上 を 1 個通過する. 等分布活荷重として単位面積当たり $p$, 等分布死荷重として単位面積当たり $q$ が載荷されるも のとする. Fig. 1 参照のこと.

6）線荷重と 1 スパン (スパン長 $=L)$ の全分布活荷 重との比を $\alpha=p L / P$, 線荷重と 1 スパンの全死荷重と の此を $\beta=q L / P$ とし, はりの中央支点モーメント $M_{B}$ の大きさが $M_{B} / P L=(2+\alpha+2 \beta) \Delta / 8$ で示されるものと する (式 (1) 参照)。ここに, $\Delta$ は任意の係数とする. 鋼道路橋示方書 ${ }^{11}$ の L-20 荷重によれば，線荷重 $5 \mathrm{tf} / \mathrm{m}$ $(49.0 \mathrm{kN} / \mathrm{m})$, 活荷重 $0.35 \mathrm{tf} / \mathrm{m}^{2}\left(3.43 \mathrm{kN} / \mathrm{m}^{2}\right)$ であ るから， $\alpha$ の值は $\alpha=0.07 L(L$ in $\mathrm{m})$ となる.

7）荷重係数として, 日本溶接協会の鋼構造物塑性設 計基準案 ${ }^{12)}$ の $1.2 D+2.1 L$ ，および $1.4(D+L)(D$ : 死荷重, $L$ : 活荷重) を, 衝撃係数, たわみ制限値は鋼 道路橋示方書 ${ }^{11}$ の規定を, 応力制限値は軟鋼の比例限度 応力度 ${ }^{13)}{ }^{14)}$ を参考に, 1 つの規準値として $\sigma_{L}=2000$ $\mathrm{kgf} / \mathrm{cm}^{2}(196.1 \mathrm{MPa})$ を用いる.

(2) 支点モーメント

Fig. 1 に示す連続ばりに線荷重 $P$, 分布活荷重 $p$, 等 分布死荷重 $q$ が作用するときの抵抗塑性モーメントは, 通常, 正の最大曲げモーメント $M_{s \max }(x)$ 之, 負の最大 曲げモーメント $M_{H}(x)$ のうちの絶対最大曲げモーメント として表示される。一方, 塑性解析の下界定理を用いた 変断面ばりの塑性設計では，不静定モーメント $M_{B}$ の大 きさは，設計に際して任意に選ぶことが可能である。こ

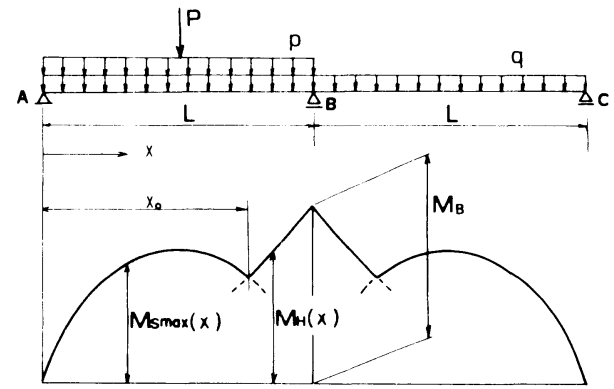

Fig. 1 Resisting plastic moment diagrams.
の場合, $M_{s \text { max }}(x)$ および $M_{H}(x)$ の大きさは，不静定モ一 メント $M_{B}$ の大きさを適当に選ぶことにより決定でき る. したがって，Fig.1に示すような放物線形状の抵抗 塑性モーメント分布を有するはりの変断面設計は無数に できることになる．結局，Fig.1に示す抵抗塑性モ一メ ント図の面積 $W_{f}=2 \int_{0}^{x_{0}} M_{s \max }(x) d x+2 \int_{x_{0}}^{L} M_{H}(x) d x,\left(W_{f}\right.$ : 重量関数に相当) を最小にするような変断面ばりの最 小重量塑性設計は，支点モーメント $\boldsymbol{M}_{B}$ の大きさをどれ くらいに選ぶかの問題になる.

文献 9)，10）によれば，Wを最小にすることを目的 とした設計では，抵抗塑性モーメントが $M_{s \max }(x)$ から $M_{H}(x)$ に変わる位置が $x_{0}=0.7071 L$ のときに最小重量 設計が得られる.このときの支点モーメント $\boldsymbol{M}_{B}$ を設計 荷重 $P, p, q$ の各荷重が, 単独に単純ばりに作用した ときの最大モーメント量を用いて表わすと, $M_{B}=(P L$ $\left.14+p L^{2} / 8+q L^{2} / 8 \times 2\right) \times 0.5858$ となる.

本研究は，たわみ，応力，せん断抵抗などの実用的制 限条件を最小重量とともに満たす設計を目的としている ため, 係数 0.5858 の代わりに任意の係数值 $\Delta$ を用いて 支点モーメント $M_{B}$ を表わすことにする．本設計は，設 計手法として，抵抗塑性モーメントの分布形状（Fig. 1) を，任意な分布形状で与えるため，支点モーメント $M_{B}$ の大きさを任意に選定することが必要である．したがっ て, $\Delta$ は, $M_{B}$ の大きさを任意に与えるための係数である. すなわち, 本研究に用いる支点モーメント $M_{B}$ は, $M_{B}$ $=\left(P L / 4+p L^{2} / 8+q L^{2} / 8 \times 2\right) \times \Delta$ となり , これを $\alpha=$ $p L / P, \beta=q L / P$ で表わすと次式のようになる.

$\frac{M_{B}}{P L}=\frac{1}{8}(2+\alpha+2 \beta) \Delta$

ここに, $\alpha=p L / P, \beta=q L / P$.

（3）抵抗望性モーメント

線荷重 $P$ のみが作用する場合の $M_{s \max }(x), M_{H}(x)$ は, 文献 9)，10）功それ゙れ， $M_{s \text { max }}(x)=P(L-x) x / L$ $-M_{B} x / L, M_{H}(x)=M_{B} x / L$ である.この $M_{s \max }(x), M_{H}(x)$ の中の $M_{B}$ の値に線荷重 $P$ のみの場合の式 $(1)$ を用 いると, $M_{s \max }(x), M_{H}(x)$ は, それぞれ次式のように示 される.

$$
\begin{aligned}
& \frac{M_{s \max }(x)}{P L}=\left(1-\frac{x}{L}\right)\left(\frac{x}{L}\right)-\frac{\Delta}{4}\left(\frac{x}{L}\right) \\
& \frac{M_{H}(x)}{P L}=\frac{\Delta}{4}\left(\frac{x}{L}\right) \cdots \cdots \cdots \cdots \cdots \cdots \cdots \cdots \cdots \cdots \cdots \cdots \cdots \cdots \cdots \cdots \cdots
\end{aligned}
$$

したがって，Fig.1に示すような荷重状態に対する $M_{s \max }(x)$ ，および $M_{H}(x)$ は，次式のようになる.

$$
\begin{aligned}
\frac{M_{s \max }(x)}{P L}= & \frac{1}{8}\left[4(2+\alpha+\beta)\left(1-\frac{x}{L}\right)\right. \\
& -(2+\alpha+2 \beta) \Delta]\left(\frac{x}{L}\right)
\end{aligned}
$$




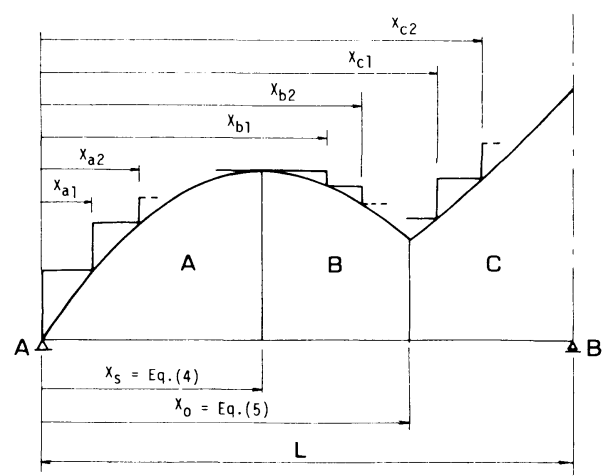

Fig. 2 Modified stepped moment distributions.

$$
\frac{M_{H}(x)}{P L}=\frac{1}{8}\left[(2+\alpha+2 \beta) \Delta+4 \beta\left(\frac{x}{L}-1\right)\right]\left(\frac{x}{L}\right) \cdots
$$

\section{（4）階段状断面}

式 (3) で示される抵抗塑性モ一メント分布は, 実際 の設計のために Fig. 2 に示すような階段状断面に置き換 えられる.そして, 最小重量を与える階段状断面の平滑 化 (Smoothing $)^{9) \cdot 10}$ は, 動的計画法 (D.P. 法) を用い て行うことができる.しかし，ここでは，設計の実用性 を考えて，普通の設計事務所などでも容易に行うことの できる断面の平滑化を考える. すなわち，Fig. 2 に示す ように抵抗塑性モーメント分布を $\mathrm{A}\left(0 \leq x \leq x_{s}\right)$, $\mathrm{B}\left(x_{s} \leq x \leq x_{0}\right), \mathrm{C}\left(x_{0} \leq x \leq L\right)$ の 3 区間に分ける.ここに, $x_{s}$ は, 正の最大曲げモーメント $M_{s \max }(x)$ の最大值を与 える断面位置を示し, $d M_{s \max }(x) / d x=0$ より次式で与 えられる.

$$
\frac{x_{s}}{L}=\frac{1}{2}-\frac{(2+\alpha+2 \beta)}{8(2+\alpha+\beta)} \Delta .
$$

また，抵抗塑性モーメント分布が $M_{s \max }(x)$ から $M_{H}(x)$ に変わる断面位置 $x_{0}$ は, $M_{s \max }\left(x_{0}\right)=M_{H}\left(x_{0}\right)$ とお き式（5）を得る.

$$
\frac{x_{0}}{L}=\left(1-\frac{\Delta}{2}\right)
$$

これら $\mathrm{A}, \mathrm{B}, \mathrm{C}$ の各区間の抵抗塑性モーメント分布 形状を最小面積でおおう階段状断面は, 式（3）が二次 の放物線であるから，それぞれの区間ごとに微分法 ${ }^{15)}$ 用いて容易に求めることができる．いま，A区間内に おける階段状断面位置を微分法で求め, その断面位置を $\mathrm{A}$ 支点からの距離として式 $(6)$ で示すと, 係数 $C_{l, i}$ は Table 1 に示すようになる.

$$
\begin{aligned}
x_{a i}= & C_{l, i} x_{s} \\
& (l=1, \cdots 6, \quad i=1, \cdots l) \cdots
\end{aligned}
$$

ここに, $l$ は A 区間内における変断面数を示し,$i$ は $\mathrm{A}$ 支点から $i$ 番目の階段状断面を示す.

B 区間における階段状断面位置は，A 区間と同様に，
Table $1 C_{l, i}$ value.

\begin{tabular}{c|c|c|c|c|c|c}
\hline$l i$ & 1 & 2 & 3 & 4 & 5 & 6 \\
\hline 1 & 1.0 & & & & & \\
\hline 2 & 0.333 & 1.0 & & & & \\
\hline 3 & 0.217 & 0.478 & 1.0 & & & \\
\hline 4 & 0.167 & 0.344 & 0.563 & 1.0 & & \\
\hline 5 & 0.130 & 0.271 & 0.430 & 0.620 & 1.0 & \\
\hline 6 & 0.108 & 0.224 & 0.350 & 0.491 & 0.661 & 1.0 \\
\hline \multicolumn{7}{c}{$C_{l, 0}=0.0(l=1,2, \cdots \cdots 6)$}
\end{tabular}

Table 1 の係数值を利用して次式のように表わすことが できる.

$$
\begin{array}{r}
x_{b j}=x_{0}+C_{m, m-j}\left(x_{s}-x_{0}\right) \cdots \cdots \\
(m=1, \cdots 6, j=1, \cdots m)
\end{array}
$$

ここに， $m$ は B 区間内における変断面数を示し, $j$ は $\mathrm{B}$ 区間内における $\mathrm{A}$ 支点側から $j$ 番目の階段状断面を 示す. 上式の係数 $C_{m, m-j}$ は Table 1 の係数 $C_{l, i}$ のサ フィックス $l, i$ を $m, m-j$ に変えたものである.

C区間内における階段状断面位置は，等間隔の階段 状断面とする.これは C 区間内の抵抗塑性モーメント 分布形状が, きわめてなめらかであることから, 分布形 状を直線とみなし，微分法により求めると等間隔に分割 されることが容易にわかる. したがって，A支点から の距離亡して C 区間内の階段状断面位置を $x_{c k}$ で示す と, 式（8）のようになる.

$$
\begin{aligned}
\frac{x_{c k}}{L}= & \frac{1}{(n-1)}\left[(n-k) \frac{x_{c 1}}{L}+(k-1)\right] \\
& (n=2, \cdots 6, \quad k=2, \cdots n)
\end{aligned}
$$

ここに， $n$ はC 区間内における変断面数を示し， $k$ は $\mathrm{C}$ 区間内における $\mathrm{A}$ 支点側から $k$ 番目の階段状断面を 示す. 式中, $x_{c 1}$ は C 区間内の最初の断面位置を示し, この位置 $x_{c 1}$ における断面は, B 区間内における最後の 断面と連続した断面となるために，式（3）を用いて $M_{s \max }\left(x_{b m-1}\right)=M_{H}\left(x_{c 1}\right)$, (Fig. 3 参照) より次式で示さ れる.

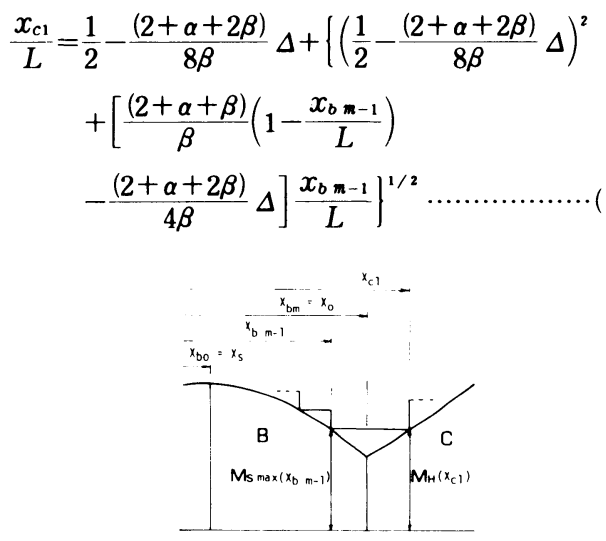

Fig. $3 M_{s \max }\left(x_{b m-1}\right)=M_{H}\left(x_{c 1}\right)$. 


$$
(m=1, \cdots 6)
$$

ここに, $x_{b m-1}$ は $m=1$ の場合 $x_{b 0}=x_{s}, m \geq 2$ の場合, 式 ( 7 ) を参照. 上式から $x_{c 1}$ が求まると上述したよう に式（8）を用いて $x_{c 1} \leq x \leq L$ の区間を等分割するこ とになる.ここで, 式 ( 8 ) は $k \geq 2, n \geq 2$ に対するも のであり, $k=n=1$, すなわち, C 区間内で断面変化が ない特別の場合は, $x_{c 1}=L$ である.

\section{（5）重量示と形状条件}

（4）で求めた階段状断面の重量を抵抗塑性モーメン トの面積，すなわち，重量関数で示すと， A, B， C の 各区間は次式のように示される.

$\mathrm{A}$ 区間 $\left(0 \leq x \leq x_{s}\right)$

$$
\begin{gathered}
W_{A}=x_{s} \sum_{i=1}^{i=l}\left\{M_{s \max }\left(C_{l, i} x_{s}\right)\left(C_{l, l}-C_{l, i-1}\right)\right\} \cdot \\
(l=1, \cdots 6, \quad i=1, \cdots l)
\end{gathered}
$$

B 区間 $\left(x_{s} \leq x \leq x_{0}\right)$

$$
\begin{aligned}
W_{B}= & \left(x_{0}-x_{s}\right)\left[M_{s \max }\left(x_{s}\right)\left(1-C_{m, m-1}\right)\right. \\
& \left.+\sum_{j=2}^{j=m}\left\{M_{s \max }\left(x_{b j-1}\right)\left(C_{m, m-j+1}-C_{m, m-j}\right)\right\}\right] \\
& (m=2, \cdots 6, j=2, \cdots m) \cdots \cdots \cdots \cdots \cdots \cdots \cdots \cdots \cdots \cdots
\end{aligned}
$$

ただし,$m=1$ の場 合は, $W_{B}=\left(x_{0}-x_{s}\right) M_{s \max }\left(x_{s}\right)(1-$ $\left.C_{m, m-1}\right)=\left(x_{0}-x_{s}\right) M_{s \max }\left(x_{s}\right)$ である.

C 区間 $\left(x_{0} \leq x \leq L\right)$

$$
\begin{aligned}
W_{c}= & \left(x_{c 1}-x_{0}\right) M_{s \max }\left(x_{b m-1}\right) \\
& +\frac{\left(L-x_{c 1}\right)}{(n-1)} \sum_{k=2}^{k=n}\left\{M_{H}\left(x_{c k}\right)\right\} \cdots \cdots \cdots \cdots \cdots \cdots \\
& (m=1, \cdots 6, \quad n=2, \cdots 6, \quad k=2, \cdots n)
\end{aligned}
$$

ただし, $n=1$ の場合は $W_{c}=\left(x_{c 1}-x_{0}\right) M_{s \max }\left(x_{b m-1}\right)$ $=\left(L-x_{0}\right) M_{s \max }\left(x_{b m-1}\right), \quad(m=1, \cdots 6)$ である.

$\mathrm{A}, \mathrm{B}, \mathrm{C}$ 各区間の変断面数 $l, m, n$ が決まると, 上式(10)〜 (12)を用いてはりの全重量 $W=W_{A}+W_{B}+W_{c}$ を求めることができる. 各区間の変断面数 $l, m, n$ と 1 スパンの変断面数 $N$ との間には, $N=l+m+n-2$ の関係がある.この 1 スパンの変断面数 $N$ が決まると, 各区間の変断面形状の組合せは $N(N+1) / 2$ 通りできる ことになる。これらの組合せに対するはり重量を上式を 用いて求め, その中から最小重量を与える変断面形状を 求めることができる.

これら各区間の変断面形状の任意の組合せをつくる際 に，連続ばりの中間支点 B の抵抗塑性モーメント $M_{B}=M_{H}(L)$ と, B 区間の抵抗塑性モーメント $M_{s \max }(x)$ の大きさの間に一定の関係がないと変断面形状として成 立しないことがある.このため各区間の変断面形状の任 意の組合せに対して Table 2 に示すような抵抗塑性モー メントの形状条件が必要となる.

以上，（3），（4)，（５）により任意の $\Delta$ 値に対する $N$ 階段状断面（ $l, m, n)$ の最適階段状断面位置なら
Table 2 Condition of $\boldsymbol{M}_{s \max }$ and $\boldsymbol{M}_{B}$.

\begin{tabular}{c|c|c|c|c}
\hline$N$ & $l$ & $m$ & $n$ & 形状条作 \\
\hline$N \geqq 3$ & $1, \cdots \cdots, N-2$ & $2, \cdots \cdots, N-l$ & $N-l, \cdots \cdots, 2$ & $M_{S_{\max }}\left(x_{b m-1}\right)<M_{B}$ \\
\hline$N$ & $1, \cdots \cdots, N$ & 1 & $N+1-l$ & $M_{S \max }\left(x_{s}\right) \leqq M_{B}$ \\
\hline$N$ & $1, \cdots \cdots, N$ & $N+1-l$ & 1 & $M_{S_{\max }}\left(x_{b N-l}\right)=M_{B}$ \\
\hline
\end{tabular}

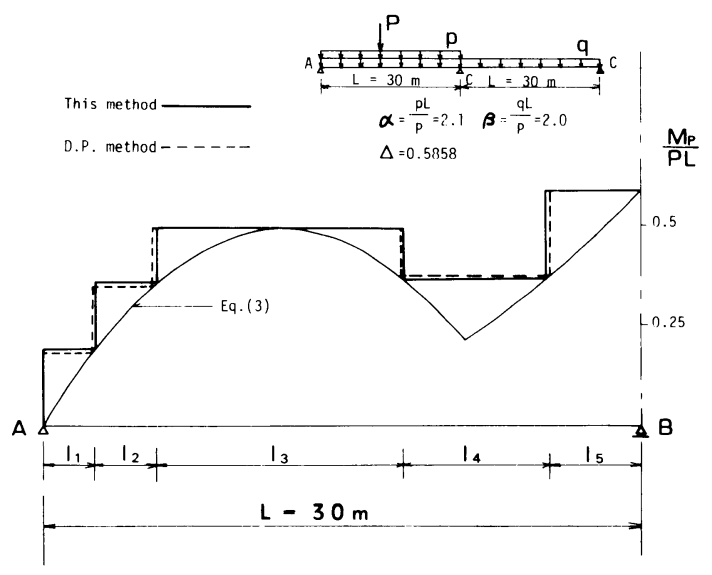

Fig. 4 Comparison of resisting plastic moment diagrams.

Table 3 Comparison of sub-length.

\begin{tabular}{c|c|c|c|c|c}
\hline & $l_{1}$ & $l_{2}$ & $l_{3}$ & $l_{4}$ & $l_{5}$ \\
\hline 本解法 & 2.62 & 3.15 & 12.40 & 7.15 & 4.68 \\
\hline D.P.法 & 2.49 & 3.00 & 12.51 & 7.50 & 4.50 \\
\hline \multicolumn{5}{c}{ (unit $: \mathrm{m}$ ) }
\end{tabular}

びに，はり重量を組織的に求めることができる.

Fig. 4 は, スパン長 $L=30 \mathrm{~m}$, 荷重比 $\alpha=2.1, \beta=2.0$, $\Delta=0.5858$ について本解法によって求めた最適階段状 断面位置と, 動的計画法 (D.P. 法 $)^{9), 10)}$ を用いて求めた ものとを比較したものである. $\Delta=0.5858$ は, 式（ 3 ） の面積が最小になるときの $\Delta$ の值（2.（2）支点モ一 メント参照) である，実線が本解析によるものを, 破線 がD.P. 法によるものを示す. 図からわかるように，A， $\mathrm{B}, \mathrm{C}$ 各区間の分割数は $l=3, m=2, n=2$ であり, D.P. 法の結果と全く同一である. さらに, 図から最適 階段状断面位置（Table 3）もほぼ同一とみなすことが できる. はりの重量は, 本解法によるものが $W_{f}=$ $0.4395 P L^{2}$, D.P. 法によるものが $W_{f}=0.4393 P L^{2}$ で あり，D.P. 法に比べて $0.05 \%$ の増加だけである.

\section{3. 必要制限条件}

\section{（1）腹板断面}

あらゆる荷重の組合せの中で, 最大せん断力 $Q_{\max }$ は 中間支点上断面に生じる. 分布荷重 $p, q$ によるせん断 力は, 静定基本系単純ばりのせん断力 $p L / 2, q L / 2$ に, $q$ による支点モーメント $M_{B}=(\alpha+2 \beta) \Delta P L / 8$ (式（1） 
参照)によるせん断力を加えたものと考えると， $Q_{\max }$ は， これらに線荷重 $P$ を考慮し， $Q_{\max }=[(2+\alpha+\beta) / 2+(\alpha+$ $2 \beta) \Delta / 8] P$ 亡なる. 日本溶接協会の鋼構造物塑性設計基 準案 ${ }^{12)}$ によれば，この $Q_{\max }$ は， $Q_{\max } / A_{w}=\tau_{\max }<\sigma_{y}$ $/ \sqrt{3}=1350 \mathrm{~kg} / \mathrm{cm}^{2}$ ( $A_{w}=$ 腹板断面積, $\tau_{\max }=$ 最大せん 断応力, $\sigma_{y}=$ 降伏点応力) でなければならない.したがっ て， $Q_{\max }$ に対する腹板断面の条件式として次式が必要 である.

$$
\{(2+\alpha+\beta) / 2+(\alpha+2 \beta) \Delta / 8\} \times P / 1350 \leq A_{w}
$$

ここに，Pは kg 単位である.

さらに，はりの塑性ヒンジ形成点では，せん断力によ る塑性モ一メントの低下に対する検討が必要である．塑 性ヒンジの形成が可能である Fig. 1 の載荷状態におい て, 塑性ヒンジ形成点は $x=x_{s}$ (Fig. 2) と中間支点上 $x=L$ である.この載荷状態に対するこれらの位置での せん断力 $Q_{x_{s}}, Q_{L}$ は, それぞれ次式のようになる.

$$
\begin{aligned}
& Q_{x_{s}}=[1 / 2-\{(2+\alpha+2 \beta) \Delta\} /\{8(2+\alpha+\beta)\}] P \\
& Q_{L}=(1+\alpha+\beta)[1 / 2+\{(2+\alpha+2 \beta) \Delta\} /\{8(2+\alpha+\beta)\}] P
\end{aligned}
$$

また，2つの断面の塑性モーメント值は, 式（ 3 ）を 用いて $M_{P}=M_{s \max }\left(x_{s}\right)$ および $M_{P}=M_{H}(L)$ であるから， それぞれの断面でのシャースパンを $a_{s}=M_{s \max }\left(x_{s}\right) / Q_{x_{s}}$, $a_{L}=M_{H}(L) / Q_{L}$ 亡する之， $a_{s}, a_{L}$ は，それぞれ次式で示 される.

$$
\begin{aligned}
& a_{s} / L=[4(2+\alpha+\beta)-(2+\alpha+2 \beta) \Delta] \\
& a_{L} / L=\{(2+\alpha+\beta)(2+\alpha+2 \beta) \Delta\} /\{(1+\alpha+\beta)
\end{aligned}
$$$$
[4(2+\alpha+\beta)+(2+\alpha+2 \beta) \Delta]\}
$$

前述の塑性設計基準案 ${ }^{12}$ によれば，シャースパン $a_{s}$, $a_{L}$, 腹板高 $d_{w}$, 腹板断面積 $A_{w}$, 片側フランジ断面積 $A_{f}$ の間に $a_{s} / d_{w}, \quad a_{L} / d_{w} \geq 1.5,0.73 a_{s} / d_{w}-0.59 \geq A_{s} /$ $A_{w}, \quad 0.73 a_{L} / d_{w}-0.59 \geq A_{f} / A_{w}$ の関係があるとき, せ ん断力による塑性モーメントの低下を考えなくてよい. いま, $\mathrm{H}$ 形断面の塑性 モーメント量 $M_{p}=\sigma_{y}\left[A_{w}\right.$ $\left.d_{w} / 4+A_{f}\left(d_{w}+t\right)\right], \quad(t=$ フランジ厚 $)$ を $M_{p} \doteqdot \sigma_{y} d_{w}$ $\left(A_{f}+A_{w} / 4\right)$ の近似式で示し, この式と上述の基準案の 条件式から $A_{f}$ を消去すると, 腹板断面 $A_{w}$ についての 条件式を得ることができる，すなわち，

$$
\begin{gathered}
\frac{M_{s \max }\left(x_{s}\right)}{\sigma_{y}\left(0.73 a_{s}-0.34 d_{w}\right)} \leq A_{w} \\
\frac{M_{H}(L)}{\sigma_{y}\left(0.73 a_{L}-0.34 d_{w}\right)} \leq A_{w} .
\end{gathered}
$$

上式の $A_{w}$ は, フランジ厚 $t$ を無視した塑性モーメント $M_{P}$ の近似式を用いても安全側である. また, $a_{s} / d_{w} \geq 1.5, a_{\llcorner} / d_{w} \geq 1.5$ の規定から, 腹板高の上限值 $d_{w} \leq 2 a_{s} / 3, d_{w} \leq 2 \alpha_{L} / 3$ を得る. しかし, この腹板高さ に対する上限值は, $a_{s}, a_{L}$ が大きいため, 通常の設計 で用いられる腹板高よりかなり大きめな值となり, 最小
重量設計に直接影響することはない，腹板に対する制限 式として, さらに腹板の幅厚比制限 $d_{w} / w \leq 70,(w=$ 腹 板厚) が必要であり，これより次式を得る.

$$
d_{w}{ }^{2} / 70 \leq A_{w}
$$

以上により，任意の $\Delta$ 值に対して $d_{w}$ を与えると式 (13)〜（17）を用いてせん断ならびに幅厚比制限に必要 な腹板断面積 $A_{w}$ を求めることができる.

\section{（2） フランジ断面}

腹板高 $d_{w}$ および腹板高 $w$ が一定 $\left(A_{w}=d_{w} \cdot w=\right.$ 一定 $)$ のはりの任意断面位置 $x=x$ における必要フランジ断面 は，次のようにして决定する，任意断面位置 $x$ におけ る $\mathrm{H}$ 形断面の塑性モーメント $M_{P}(x)$ とフランジ断面積 $A_{N}(x)$, フランジ厚 $t(x)$ の間には, 次式が必要である.

$$
\left.M_{p}(x)=\sigma_{y}\left[A_{w} d_{w} / 4+A_{\curlywedge}(x) \mid d_{w}+t(x)\right\}\right]
$$

上式の左辺の $M_{p}(x)$ 值は, 前節 2. において, 与えら れた $\Delta$ 値に対して最小重量（抵抗塑性モーメントの面 積最小）を与える $N$ 階段状断面形（たとえば, Fig. 4) が決定されると, 式（3）を用いて容易に求めることが できる.したがって，はりの任意断面位置 $x$ における 必要フランジ断面は, 式 (18) を満たす $A \lambda(x), t(x)$ を 求めることになる.

このほか, フランジ断面は幅厚比制限を受ける.この フランジ断面の幅厚比制限 $b / t \leq 17$ より, 板厚は $\left[A_{s} / 17\right]^{1 / 2} \leq t$ を必要とするから，この関係を式 (18) に用いてフランジ断面 $A_{\gamma}(x)$ について整理すると, $A_{\lambda}(x)$ についての三次式, 式 (19) を得ることができる.

$$
\begin{aligned}
& A_{\mathcal{J}}(x)^{3}-\left(17 d_{w}{ }^{2}\right) A_{\mathcal{J}}(x)^{2}+\left\{3 4 \left[M_{p}(x) / \sigma_{y}\right.\right. \\
& \left.-A_{w} d_{w} / 4\right] d_{w} \downarrow A_{\mathcal{J}}(x) \\
& -17\left[M_{p}(x) / \sigma_{y}-A_{w} d_{w} / 4\right]^{2}=0 \ldots \ldots \ldots \ldots
\end{aligned}
$$

上式から必要フランジ断面積 $A ⿱ \lambda(x)$ が得られ, $[A(x) / 17]^{1 / 2} \leq t(x)$ より必要フランジ厚 $t(x)$ を得るこ とができる.一方, 塑性ヒンジが形成される断面 $\left(x=x_{s}\right.$,

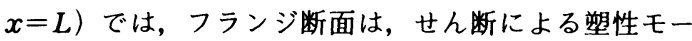
メントの低下に関する規定, $A_{f} / A_{w} \leq 0.73 a / d_{w}-0.59$, ( $a=$ シャースパン) をも満足しなければならない.この 規定と, 式 (18) より, 塑性ヒンジ断面でのフランジ厚は, 次式を満足するものでなければならない.

$$
\begin{aligned}
& {\left[M_{p}\left(x_{\bar{\imath}}\right)-\sigma_{y} A_{w} d_{w}\left(0.73 a_{\bar{\imath}} / d_{w}-0.34\right)\right] /} \\
& {\left[\sigma_{y} A_{w}\left(0.73 a_{\bar{\imath}} / d_{w}-0.59\right)\right] \leq t\left(x_{\bar{\imath}}\right) \ldots \ldots \ldots .}
\end{aligned}
$$

ここに, $\bar{i}$ は塑性ヒンジ断面 $\left(x=x_{s}, x=L\right)$ に関する サフィックスを示し, $\bar{i}=S$, あるいは $\bar{i}=L$ である. したがって, $x=x_{i}$ 断面では式 (19), 式 (20) から得 られる $t\left(x_{i}\right)$ のうち大きい方が必要フランジ厚となる.

このようにして，（1），（２）により必要腹板断面積 $A_{w}$ および必要フランジ断面積 $A$ 份 $(x)$ が求まると, $N$ 階 段状断面ばりの 1 スパン分のはり重量 $W$ は, 次式で与 


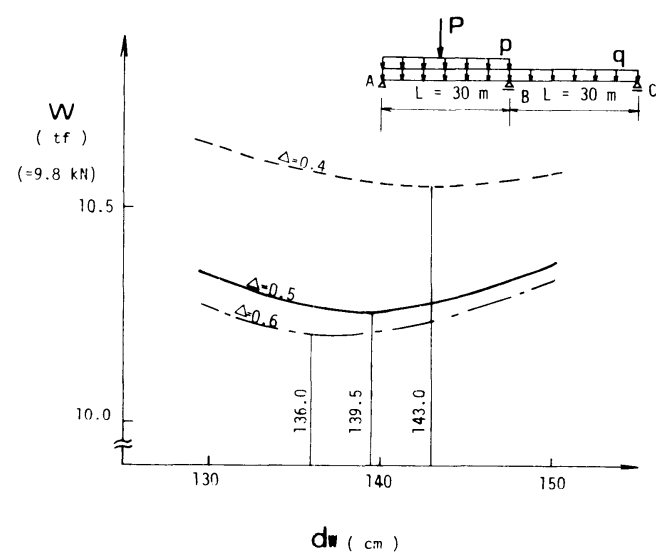

Fig. 5 Structural weight vs depth of web relationships.

えられる。

$$
W=\left[2 \sum_{i=1}^{i=N} A_{\curlywedge}(x) \cdot l_{i}+A_{w} L\right] \rho
$$

上式にて, $N$ は1 スパン内における変断面数, $l_{i}$ は分 割区間長 (Fig. 4 参照)，Lはスパン長， $\rho$ は鋼材の密 度を示す，上式を用いてはり重量 $W$ を最小にする析高 $d_{w}$ を求めることができる.

Fig. 5 は，スパン長 $30 \mathrm{~m}+30 \mathrm{~m}$, 鋼析の上に鉄筋コ ンクリート床版（非合成） $300 \mathrm{~cm} \times 20 \mathrm{~cm}$ を考え，1 ス パンの変断面数 $N=5$ の階段状断面に対して, $\Delta=0.4$, $0.5,0.6$ の場合について, はり重量-はり高関係を求め たものである．縦軸にはり重量 $W(\mathrm{tf})$ をとり，横軸には り高 $d_{w}(\mathrm{~cm})$ をとってある.この図から， $\Delta=0.4,0.5$, 0.6 に対して最小重量を与えるはり高は, それぞれ $d_{w}$ $=143 \mathrm{~cm}, 139.5 \mathrm{~cm}, 136.0 \mathrm{~cm}$ であることがわかる.

\section{（3）たわみ，応力度制限}

上述のように, 2. 変断面設計においては, ある $\Delta$ 値 に対して抵抗塑性モーメント分布の面積（重量関数）を 最小にする階段状変断面形状が決定された。ささらに，3.

（1），（2）では，与えられた $\Delta$ 值に対して最小重量 を与えるはりの断面寸法值が決定された。ここでは, 前 節までに得られた断面寸法值を用いて, 設計荷重 L-2011 によるたわみ，応力計算を弾性計算により行う。算定さ れたたわみ, 応力度は, それぞれ次式の制限値を満たす ことが必要である.

$$
\delta \leqq \delta_{a 11}^{111}
$$

$\sigma \leqq \sigma_{L}$

上式を満たす設計の中で，重量最小を与える設計を求 める. 以下に, 本設計の手順の概略, および, 設計フロ一 チャートを示すと次のようである.

1）2. 節において, 任意の $\Delta$ 值に対して，抵抗塑性 モーメント分布の面積を最小にする階段状変断面形状を

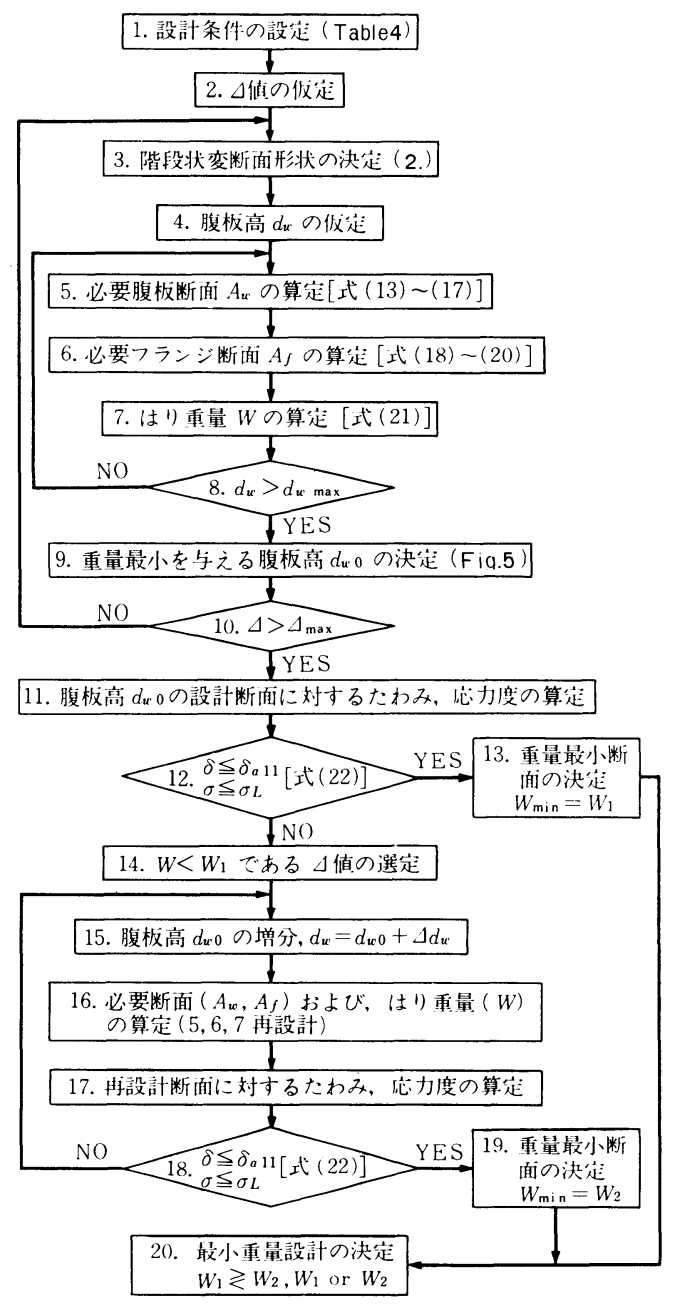

Fig. 6 Design Flow Chart.

決定する.

2） 3. 節において, これらの $\Delta$ 值に対して必要制限 条件 [式 (13)一式(20)] を満たし, 重量最小 [式 (21)] を与えるはり高 $d_{w}$, および，断面寸法值を決定する.

3） 1)，2）で決定された設計断面に対して，たわみ， 応力度計算を行い, その中で式（22）を満たす設計を $W_{1}$ とする.

4）3）において,式 $(22)$ を満たさなかった設計 ( $\Delta$ 值) の中ではり重量 $W$ が $W<W_{1}$ である $\Delta$ 値を選定する.

5） $W<W_{1}$ である設計断面に対して，はり高 $d_{w}$ を 増分させ 3. 節に戻って再び，必要制限条件を満たす断 面寸法值（再設計）を決定する.

6) 再設計断面が式（22）を満たすまではり高 $d_{w}$ を 増分させて再設計を繰り返す。再設計の中で, 式 (22) を満たす設計を $W_{2}$ とし，3) で求めた $W_{1}$ の設計との重 量比較を行い，重量が小さい方を最小重量設計とする. 
これらの設計手順をフローチャートにすると Fig. 6 の ようになる。

以上のようにして, たわみ，応力度制限を同時に満た す変断面ばりの最小重量塑性設計を組織的に行うことが できる。

\section{4. 設計計算例}

Table 4 の設計条件のもとで種々な $\Delta$ 值に対する設計 を行った. 設計条件のうち, 設計荷重, 衝撃係数, たわ み制限值については, 日本道路協会の道路橋示方書 ${ }^{11)} の$ 規定值を用い, 荷重係数は, 日本溶接協会の鋼構造物塑 性設計基準案 ${ }^{12)}$ のものを用いた。表中, 応力度制限値は, 文献 13），14）などから軟鋼の比例限度态力值 1920 $2000 \mathrm{~kg} / \mathrm{cm}^{2}$ を参考に, 本設計では 1 つの規準値として $2000 \mathrm{~kg} / \mathrm{cm}^{2}$ を選んだ。

Fig. 7 は, Table 4 の設計条件のもとで各設計 ( $\Delta$ 值)

Table 4 Design Condition.

\begin{tabular}{|c|c|c|c|}
\hline スパン長 & $30 m+30 m$ & 鎆 & $\begin{array}{c}\mathrm{SS} 4 \mathrm{l} \\
\sigma_{y}=240\left(\mathrm{kgf} / \mathrm{cm}^{2}\right. \\
(235.4 \mathrm{MPa})\end{array}$ \\
\hline $\begin{array}{l}\text { 鉄筋コンク } \\
\text { 少一步版 } \\
\text { (非苓成) }\end{array}$ & $300 i \mathrm{~cm} \times 20 \mathrm{~cm}$ & 衝撃係数 ${ }^{111}$ & $i=20 /(50+L)$ \\
\hline 設計荷重 ${ }^{111}$ & $\mathrm{~L}-20$ & たわみ制限倠 & $\delta_{a 11}=\frac{L}{20(0) 00 / L}$ \\
\hline * 何﨡係数 ${ }^{12)}$ & 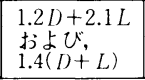 & \begin{tabular}{r|}
$13 i, 141$ \\
心力制限值
\end{tabular} & $\begin{aligned} \sigma_{L} & =2000 \mathrm{kgf} / \mathrm{cm}^{2} \\
& (196.1 \mathrm{M} \mathrm{Pa})\end{aligned}$ \\
\hline
\end{tabular}

荷重係数 $(l)$ ：死荷重, $L$ ：活荷重

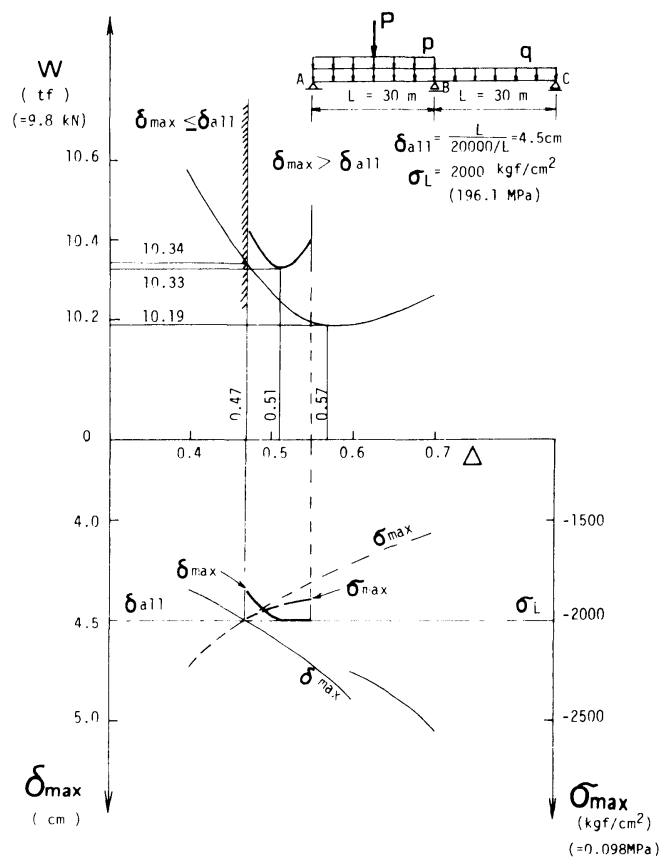

Fig. $7 W-\Delta-\delta_{\max }-\sigma_{\max }$ relationships.
に対して求めた，はり重量- $\Delta$ 值一最大たわみ量-最大応 力度 $\left(W-\Delta-\delta_{\max }-\sigma_{\max }\right)$ の関係を示したものである. 図は横軸に $\Delta$ 值を示し，それに対する1 スパン分のは り重量 $W(\mathrm{tf})$ を縦軸上段に示し，はりのスパン中央付近 の最大たわみ量 $\delta_{\max }(\mathrm{cm})$ と, 中間支点上断面の最大 応力度 $\sigma_{\max }\left(\mathrm{kg} / \mathrm{cm}^{2}\right)$ を縦軸右下段に示したものである. 図に示した設計は， $\Delta$ 值を 0.4 から 0.7 まで 0.01 きざ みで行ったものである。

図の上段におけるはり重量一 $\Delta$ 值曲線（細実線）は, 曲げとせん断の必要制限条件（3．節）を同時に満たす 断面の中で, 重量最小を与えるはり重量- $\Delta$ 值曲線とし て示されている. 図から重量最小である設計（ $\Delta$ 値）は, $\Delta=0.57$ であり, このときのはり重量は $W=10.19 \mathrm{t}$ で ある.しかし，縦軸下段に示すように，このときは，最 大応力度 $\sigma_{\max }$ は制限值内 $\left(\sigma_{\max }<\sigma_{L}\right)$ にあるが, 最大 たわみ量 $\delta_{\max }$ は制限值をかなりこえている $\left(\delta_{\max }>\delta_{a 11}\right)$.

図の上段において，ハッチング (斜線) から左側 $\Delta \leq 0.47$ の範囲が $\delta_{\max } \leq \delta_{a 11}$, ハッチングの右 側 $\Delta>0.47$ の範囲が $\delta_{\max }>\delta_{a 11}$ の設計である.いまここで, たわみ制限を満たさない $\Delta>0.47$ の $\Delta$ 值に対して, 再 度 3.（3）で述べたように，はり高 $d_{w}$ を増分させ制限 条件を満たすように再設計を行った。その結果, はり重 量- $\Delta$ 值関係は, 図の上段に示す $\Delta=0.47$ のところから 描かれている太い実線のようになる. また，これらの再 設計 $(\Delta=0.47 \sim 0.55)$ に対する $\delta_{\max }$ 線， $\sigma_{\max }$ 線は, 図の下段に示す太い実線 $\left(\delta_{\max }\right.$ 線), ならびに, 太い破 線（ $\sigma_{\max }$ 線）のようにそれぞれ示される.

したがって，本設計の制限条件をすべて満たして重量 最小となる設計は, $\Delta=0.51, W=10.33$ tf として得ら れる.このときの最大たわみ量は，はりのスパン中央付 近に生じ $\delta_{\max }=4.49 \mathrm{~cm}$ であり，また，最大応力度は， 中間支点上断面に生じ $\sigma_{\max }=-1930 \mathrm{~kg} / \mathrm{cm}^{2}$ であった. なお，図の下段に示した $\delta_{\max }$ 線が， $\Delta=0.6$ のところで 不連続になっているのは， $\Delta$ の範囲が $0.4 \leq \Delta \leq 0.6$ と， $0.6 \leq \Delta \leq 0.7$ では，階段状断面の形状が急に変化する ためである.すなわち， $0.4 \leq \Delta \leq 0.6$ の範冊では，階 段状の変断面数が $0 \leq x \leq x_{s}$ (A区間，Fig. 2 参照）で 3 変断面数, $x_{s}<x \leq x_{0}$ (B 区間) と $x_{0}<x \leq L$ ( $\mathrm{C}$ 区間) でそれぞれ 2 変断面数であったのが, $\Delta$ の変化ととも に, $0.6<\Delta \leq 0.7$ の範讲では変断面数が, $\mathrm{A}$ 区間 $2, \mathrm{~B}$ 区間 $2, \mathrm{C}$ 区間 3 変断面数と変化したためである． $\sigma_{\max }$ 線については， $\delta_{\max }$ 線にみられるような急激な変化は みられなかった。

Fig. 8 は, 本設計 (Fig.7) で求めた $\Delta=0.51$ に対す る階段状の変断面形状と，重量最小化のみを目的とした 文献 9)，10）と同じ方法で求めた $\Delta=0.5858$ (2.（2） 


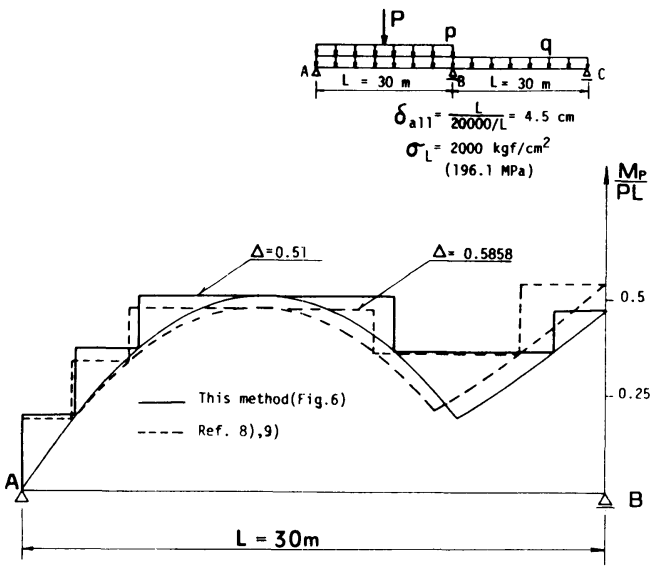

Fig. 8 Comparison of resisting plastic moment diagrams $(\Delta=0.51, \Delta=0.5858)$.

支点モーメント参照）に対する変断面形状の比較を示し たものである．図に示す変断面形状は，腹板高さと腹板 厚さを一定としているため, フランジ断面の変化を示す ものである. また，両設計で得られた各設計値の比較を 示すと, Table 5 のようになる. 重量最小化のみを目的 とした設計は，表に示すようにたわみ制限值 $\left(\delta_{a 11}=4.5 \mathrm{~cm}<\delta_{\max }=5.14 \mathrm{~cm}\right)$ を満たしていない.

Fig. 8 は，スパン長 $30 \mathrm{~m}+30 \mathrm{~m}$ に対する 1 スパン分 の鋼重 $W$ と， 1 スパンにおける変断面数 $N$ の関係を示 したものである. $N=6$ 以上の変断面数の場合，鋼重 $W$ にあまり差はなく,$W=10.25 \mathrm{tf}$ の線に漸近してい ることがわかる.また， $N=3$ と変断面数が少なくなる と，鋼重が急激に増加していくことがわかる．この図か ら，溶接面での経済性と鋼重の経済性を考え併せるとす るならば，変断面数は， $N=4$, あるいは， $N=5$ が適 当と思われる.

Fig. 10 は，スパン長 $30 \mathrm{~m}+30 \mathrm{~m} ， 1$ スパン変断面数 $N=5$ のはりについて，応力制限值を一定（ $\sigma_{L}=2000$ $\left.\mathrm{kg} / \mathrm{cm}^{2}\right)$ とし, たわみ制限値 $\delta_{\text {Limit }}$ を種々変化させた場 合のはり重量 $W$-たわみ制限值 $\delta_{\text {LImit }}$ 関係を示したもの である.たわみ制限が $\delta_{\mathrm{LImit}}=L / 800$ と厳しくなると， たわみ制限を満たすようにはりの剛性を增加させるた め，鋼重が急に增加することがわかる．また，たわみ制

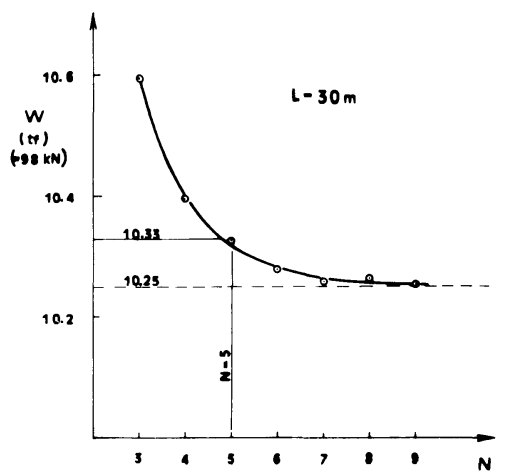

Fig. 9 Structural weight vs stepped numbers ralationships.

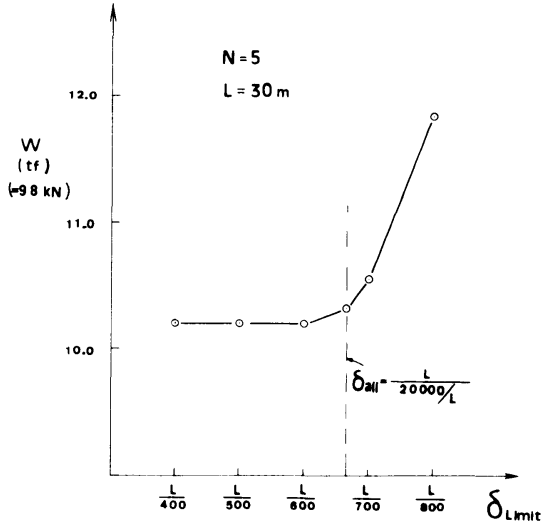

Fig. 10 Structural weight vs deflection limit relationships.

限を $\delta_{\mathrm{LImIt}}=L / 600 \sim L / 400$ とゆるくすると鋼重 $W$ は， 一定値を示すようになる。これは，たわみ計算の前に抵 抗塑性モーメント，および，女ん断抵抗に必要な断面之 して決定されたはり断面が，それだけで十分たわみ制限 値を満たす断面となっているからである.

このように，本設計で得られる最適断面は，抵抗塑性 モーメント，および，せん断抵抗に対してぎりぎり必要 な経済断面になっているが，作用荷重によるたわみ，応 力などについては必ずしも制限值ぎりぎりの断面ではな い。しかし，一度，抵抗塑性モーメント，せん断抵抗に 対して決められた断面に対して,作用荷重によるたわみ, 応力の制限値に入るようにはり高 $d_{w}$ を増分させた場合

Table 5 Comparison of Design.

\begin{tabular}{|c|c|c|c|c|c|c|c|c|c|c|}
\hline \multirow{3}{*}{ 設計法 } & \multirow{3}{*}{$\Delta$ 㑤 } & \multirow{3}{*}{$\begin{array}{c}\text { はり重量 } \\
W \\
(\mathrm{tf})\end{array}$} & \multirow{3}{*}{$\begin{array}{c}\text { 最大たわみ量 } \\
\delta_{\max } \\
(\mathrm{cm})\end{array}$} & \multirow{3}{*}{$\begin{array}{c}\text { 最大縁応力度 } \\
\text { (中間支点) } \\
\sigma_{\max }\left(\mathrm{kg} \mathrm{f} / \mathrm{cm}^{2}\right)\end{array}$} & \multicolumn{6}{|c|}{ 断面 寸法值 $(\mathrm{mm})$} \\
\hline & & & & & \multirow{2}{*}{$\begin{array}{l}\text { 腹 板 } \\
d_{w} \times w\end{array}$} & \multicolumn{5}{|c|}{ フランジ $b \times t$} \\
\hline & & & & & & (1) & (2) & (3) & (4) & (5) \\
\hline 本設計 & 0.51 & $\begin{array}{c}10.33 \\
(101.2 \mathrm{kN})\end{array}$ & 4.49 & $\begin{array}{c}-1930 \\
(-189.3 \mathrm{MPa})\end{array}$ & \begin{tabular}{|c|}
1485 \\
$\times$ \\
22
\end{tabular} & $\begin{array}{c}136 \\
\times \\
8\end{array}$ & $\begin{array}{c}271 \\
\times \\
16\end{array}$ & $\begin{array}{c}379 \\
\times \\
23\end{array}$ & \begin{tabular}{|c|}
271 \\
$\times$ \\
16
\end{tabular} & $\begin{array}{c}365 \\
\times \\
22\end{array}$ \\
\hline $\begin{array}{l}\text { 文 献 } \\
9), 10)\end{array}$ & 0.5858 & $\begin{array}{c}10.12 \\
(99.2 \mathrm{kN})\end{array}$ & 5.14 & $\begin{array}{c}-1790 \\
(-175.5 \mathrm{MPa})\end{array}$ & \begin{tabular}{|c|}
1351 \\
$\times$ \\
20
\end{tabular} & $\begin{array}{c}136 \\
\times \\
8\end{array}$ & \begin{tabular}{c|}
306 \\
$\times$ \\
18
\end{tabular} & $\begin{array}{c}425 \\
\times \\
25\end{array}$ & $\begin{array}{c}323 \\
\times \\
19\end{array}$ & $\begin{array}{c}476 \\
\times \\
28\end{array}$ \\
\hline
\end{tabular}

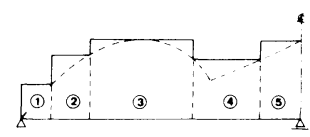


は，抵抗塑性モーメント，せん断抵抗に対してもぎりぎ り必要とされる経済断面であると同時に, たわみ, 応力 のよ゙ちらかについても必要最小限の最適な設計となって いる.

\section{5. 結 論}

作用荷重時におけるたわみ制限, および, 応力度制限 を考虑した 2 径間連続ばりの最小重量塑性設計を行い, 変断面設計の方法について考察を加えた。 また, 重量最 小化のみを目的とした変断面塑性設計との比較を示し,

はり重量, たわみ, 応力度について検討を加えた。

以下に, 本研究で得られた主な結果, および, 検討事 項は次のようである.

（1）変断面設計における階段状断面位置は, 本設計 のように抵抗塑性モーメント分布形状を A， B，Cの 3 区間に分けた微分法によれば，動的計画法 (D.P. 法) とほぼ同じ結果が得られる。

（2）中間支点モーメント $M_{B}$ を任意の係数 $\Delta$ を用い て表わすことにより，抵抗塑性モーメントの分布形状そ のものを変数として扱える.このため, 任意の抵抗塑性 モーメント分布形状に対する最適階段状断面位置，およ び，はり重量（重量関数）が一連の式で表示でき，これ らを組織的に求めることができる.

（3）せん断に必要な腹板断面積を設計荷重,および, 係数 $\Delta$ を用いて表わした。これらを用いて, 腹板高, 腹板厚を一定とした場合の連続ばりの抵抗塑性モーメン 卜に必要な $\mathrm{H}$ 形断面の重量最小化を図った。

（4）作用荷重時におけるたわみ制限，および，応力 度制限を考虑した 2 径間連続ばりの最小重量塑性設計の 方法, および, 設計手順を設計例（Fig.7）により示した.

（5）重量最小化のみを目的とした変断面塑性設計と の比較設計を示し, はり重量, たわみ, 応力度, 抵抗塑 性モーメントの分布形状の違いについて考察を行った。

（6）はり重量と変断面数との関係を求めた. 溶接面 での経済性と鋼重の経済性を考え併せると, 等スパン 2 径間連続ばりの 1 スパンにおける変断面数は $N=4,5$ が適当と思われる.

（7）応力度制限值を一定とし，たわみ制限值を種々 変化させた場合のはり重量とたわみ制限値との関係を求 めた。

なお, 今後の問題として, 本設計法を多径間連続ばり, あるいは, ラーメン構造などの高次不静定構造にいかに
適用していくかの問題が残されているように思われる. これらの問題については, 今後検討を加えていくつもり である.

\section{参考文 献}

1）伊藤 学・前田幸雄・深水正保・鳥居邦夫 - 正道博照： 塑性設計法の歩道橋への適用, 土木学会誌, Vol. 54, pp. 40 47, 1969 年 5 月.

2) 成岡昌夫-中村恒善: 骨組構造解析法要覧, 培風館, pp. 290 310, 1976 年 4 月.

3) Gallagher, R.H. and Zienkiewicz, O.C. (川井忠彦 戸川隼人監訳)：最適構造設計, 培風館, pp. 247 262, 1977 年 6 月.

4) Melchers, R.E. : Service Load Deflections in Plastic Structural Design, Proc. of ICE, Vol. 69, Part 2, pp. 159 174, March, 1980.

5) Azad, A.K. : Optimum Design of Three-Span I -Beams, Proc. of ASCE, Vol. 107, No.ST-12, pp. 2433 2437, December, 1981.

6）石川信隆・三原徹治・香月 智：使用時と終局時の制約 を同時に考虑した骨組構造の最適設計に関する一考察, 土木学会第 38 回年次学術講演会講演概要集, 第 1 部門, I - $215, p p .429 \sim 430,1983$ 年 9 月.

7）石川信隆・三原徹治・香月 智・古川浩平：弾性および 塑性設計基準を同時に考虑した骨組構造の最適設計法 (英 文), 土木学会論文集, 第 350 号 / I -2, pp. $97 \sim 104$, 1984 年 10 月.

8）伊藤 満・福本唀士：実用的制限条件を考虑した変断面 ばりの塑性設計, 土木学会第 35 回年次学術講演会講演概 要集, 第 1 部門, I - 345, pp. 683 684, 1980 年 10 月.

8）福本唀士・伊藤 満：变断面はりの塑性設計に関する一 考察, 土木学会論文報告集, 第 185 号, pp.1 7, 1971 年 1 月.

10) Fukumoto, Y. and Ito, M. : Minimum Weight Plastic Design of Continuous Beams, Proc. of ASCE, Vol. 107, No. ST-7, pp. 1263 1277, July, 1981.

11）道路協示方書・同解説，I共通編，II 鋼橋編，日本道路 協会, 1980 年 2 月.

12）銅構造物塑性設計基準案，日本溶接協会塑性設計研究委 員会, 1968 年.

13）前田幸雄・竹内修治：塑性設計法による横断歩道橋の最 小重量設計とその自動化について, 土木学会論文報告集, 第 168 号, pp. 1 13, 1969 年 8 月.

14）小西一郎・横尾義貫・成岡昌夫・丹羽義次：構造力学 第 1 巻, 丸善, p 248, 1982 年 2 月.

15）たとえば, 細川弥重・田島二郎：合成析の設計,オーム社, pp. 109 110, 1971 年 8 月.

(1984. 5. $18 \cdot$ 受付) 